\title{
Role of Organic Crop Production System in Biological Diseases as a Control Agents
}

\author{
Rohit Kumar Verma ${ }^{1(\mathbb{D})}$, Mahipal Singh Sankhla ${ }^{2, *(\mathbb{D})}$, Sonali Kesarwani ${ }^{3}{ }^{\mathbb{D}}$, Kapil Parihar ${ }^{4(\mathbb{D})}$, Swaroop \\ S. Sonone ${ }^{5}$ (D) Ekta B. Jadhav ${ }^{\text {(D) }}$, Leena Bhardwaj ${ }^{6}$ (D) \\ 1 Dr. APJ Abdul Kalam Institute of Forensic Science \& Criminology, Bundelkhand University, Jhansi, India; \\ rohitlyn8423@gmail.com (R.K.V.); \\ 2 Department of Forensic Science, Vivekananda Global University, Jaipur, Rajasthan, India; mahipal4n6@gmail.com \\ (M.S.S.); \\ 3 Department of Forensic Science, School of Basic and Applied Sciences, Galgotias University, Greater Noida, India; \\ sonalikesarwani743@gmail.com (S.K.); \\ 4 Forensic Scientific Assistant, State Forensic Science Laboratory, Jaipur, Rajasthan, India; kparihar94@ gmail.com (K.P.); \\ 5 Government Institute of Forensic Science, Aurangabad, Maharashtra, India; sononeswap4@gmail.com (S.S.S.); \\ ektajadhav3663@gmail.com (E.B.J.); \\ 6 Institute of Higher education and Research center, Delhi leena.bhardwaj2000@gmail.com (L.B.); \\ * Correspondence: mahipal4n6@gmail.com (M.S.S)
}

Scopus Author ID 57219964786

Received: 3.06.2021; Revised: 10.07.2021; Accepted: 14.07.2021; Published: 13.08.2021

\begin{abstract}
Nowadays, the biological diseases in crop production are continuously increasing day by day. Organic agriculture has considerably augmented in significance in the current eras. Crop diseases are also a severe delinquent over the decades, and it's a chief hazard for the yield food manufacture. Biological control agents for herbal syndromes are presently existence inspected as substitutes to artificial insecticides owing to their apparent improved level of care and negligible ecological influences. It affects the plants also by the biological diseases of the organic food production. Plant diseases can disturb florae by intrusive with numerous procedures such as the absorbance and translocation of water and nutrients, photosynthesis, flower and fruit growth, plant growth and expansion, and cell separation and increase. In this paper, we explain how biological diseases affect organic crop production.
\end{abstract}

Keywords: organic; biological diseases; delinquent; apparent; crop production.

(C) 2021 by the authors. This article is an open-access article distributed under the terms and conditions of the Creative Commons Attribution (CC BY) license (https://creativecommons.org/licenses/by/4.0/).

\section{Introduction}

The drastic growing population (approx. 9 billion by 2050) and global climatic change will have significant demands over natural resources, including the availability of water and land for food-crop production. The serious and major problems are crop diseases that greatly affect food production and its variety [1]. The solution to this issue is somewhat managed by strengthening consumer awareness along with EU legislation prohibiting access to other agricultural resources like agrichemicals and the dearth of consumer acceptance of genetically modified crops, especially in Europe, and strict regulatory procedures in regards to their registration, initiate to search for new and sustainable agricultural practices. The current major challenge facing stakeholders is ways to implement a sustainable crop production system that aids in improving the above-stated problems, which led to global food security at risk. One such example of integrated sustainable crop production is the one that includes useful microorganisms like bacteria that can contribute to plant growth, either directly through 
activities like bio-fertilization and photostimulation or indirectly by suppressing pathogens. An organic method that incorporates the use of bacterial-derived agents may provide an opportunity to reduce the use of agrichemicals [2]. The use of biological controls to treat plant diseases, especially soil-borne diseases, has been the subject of ongoing research for several decades. It has been found that the most commonly applied and practiced way to control the biological inoculative, or inundative diseases [3] depends on the purposeful incorporation of living organisms to overpower the activity of plant pathogens. However, initially, its utility in the real-world as an alternative to disease management was the basis for early testing of this discipline, the field of biological disease control has encouraged research and discovery beyond the aim of finding solutions or products for use in crop production systems. The discussions can be made that the greatest benefit of the results from research programs that focus on the natural control of soil-borne plant diseases is to inform our understanding the microbial nature of soil and to identify useful microbial bodies and processes that work along with saprophytic plant-related microorganisms to suppress diseases [4] and can retain in soil environments [5,6]. In recent years, the role of fungi in the environment has been extensively exploited to control and regulate plant pathogens in forestry systems, horticulture, and agriculture. The role of fungi in the environment has been extensively exploited. Many fungi have special properties and mechanisms that effectively aids them in treating both root and foliar diseases and damages that trigger due to pathogenic fungi. Mycoparasitism, a process in which a mycoparasites or fungus derives its nutrients from other fungi (host), is used to control bacteria [7, 8]. Since the bio-controlling agents for plant diseases have increased safety and the least environmental impacts, they are now being evaluated as substitutes and alternatives to synthetic/artificial pesticides. Several mechanisms of fungal bio-controlling agents aid in the production of enzymes or antibiotics, defense from plant host, helps to control pathogens, including mycoparasites, and competition for nutrients requirement. However, in effectively controlling plant diseases, these methods can threaten non-targeted species, plants, animals (both aquatic and terrestrial), insects, soil microbes, saprophytic and mycorrhizal fungi, even human beings. Some of the non-targeted impacts associated with fungal bio-controlling agents are reducing the colonization of plant roots by mycorrhizal fungi, mycoparasitism of mycorrhizae, and mushroom disorders Rhizobium species nodulation, and changes in plant growth. Moreover, the genera Gliocladium has been associated with shellfish toxicity and Trichoderma with respiratory disorders in humans. Biological controlling agents, like Talaromyces flavus, Pythium oligandrum, Coniothyrium minitans, and Ampelomyces quisqualis have potential harmful mechanisms against non-targeted bacteria, fungi, plants, and animals [9]. The widespread use of pesticides has also had a significant effect on the environment and public health. Research is being carried out in many institutes to find suitable environment-friendly methods to replace the currently used pesticides. In such a case, pest control through biological agents is as promising as the use of other chemicals. It is generally known that biological controlling agents are much safer and environment friendly than relying on the use of a huge amount of pesticides, fungicides, and other antimicrobial chemicals. Increasing research and scientific interest towards biological control of plant-based pathogens and plant disease responds to the rising public concern about chemical pesticides. However, there is still an equally important need to control currently partially controlled biologically or uncontrolled pathogens by general traditional methods. Therefore, the importance of expense over chemical control must not matter regarding bio-control since it can prove its value reasonably [10]. These biocontrol substitutes must be reliable, efficient, economical, environment friendly, and 
consistent before they can become an integral part of plant disease controlling agents. To fulfill these requirements, the correct understanding of biocontrol agents' overall nature and biology in question is very important, which is far restricted in many conditions. In addition, biocontrol agents can also be genetically modified to develop superior strains with delivery systems that improve their activity and characteristics [11]. Cook and Baker defined 'Biological control' as "the reduction in the disease-causing activity of pathogens or in the amount of inoculum that is carried out by using one or more organisms other than man" [12]. Based on this broad definition, the organisms and processes involved in biological control include: (I) hypo-virulent or avirulent populations of pathogenic species, (II) modified plants having resistance to pathogens, and (iii) antagonistic microorganisms. Biological control can be achieved in many ways, including plant breeding, introducing large amounts of antagonism, and certain specific cultural practices by altering microbial balance [12]. Organic farming (OF) can be defined as "an ecosystem that is environmentally friendly, economically and socially, providing a sustainable supply of safe and healthy food and fiber, minimal possible loss of nutrients and energy, and small environmental impacts, as regulated by certification agencies" $[13,14]$. OFA has grown significantly globally in the last 20 years, including in developing countries, with the global market for natural products reaching nearly \$ US 72 billion in 2013 [15]. The OF is governed by the idea that all environmental processes within the agro-ecosystem system are self-sufficient and that management should aim at achieving and supporting self-regulation through environmental processes. This is set out in detail at the OF levels as organized by the IFOAM (International Federation of Organic Agricultural Movements). Therefore, solutions to the problems are sought primarily within the natural possibilities of the agricultural system. Biological control is the striking and ideal management strategy for those post-harvest diseases in which the pathogen intervenes throughout or after harvest [16]. Several post-harvest diseases in citrus fruits and pomegranate are triggered by pathogens that need the injured and wounded plant area to get into and start the infection. Contacting different fruits with machinery and shipping containers during harvesting, handling, and shipping may result in injury, wound puncture, stem removal, and damage to fruit surfaces, which can be a promising source of entry for pathogens to cause infection. In addition, a high percentage of the fruits will be stored in a well-controlled environment. Temperature, atmospheric composition, and relative humidity can all be regulated and controlled more accurately. This infection timing and controlled environment make post-harvesting systems almost perfect conditions from allowing the introduction of biological controlling agents to prevent the decay of the plant system. The postharvest and handling are possible in harvesting plant systems by adding a bio-control agent to the plant area that needs protection, in the right place for it to work properly, and control environmental conditions [17] effectively. Similarly, applying biopesticides to the fruits before storage is possible in the post-harvesting and handling system. The Bio-save products contain bacteria resistant to a variety of substances used during post-harvest management, such as diphenylamine and the fungicides (imazalil and thiabendazole) used to protect scald and rot, respectively $[17,18]$. There are several ways applied to treat fruits before packing; in all the cases, the fruit is firstly cleaned, filtered to remove damaged or rotten fruit, and then placed in storage containers. Usually, the fruit is cleaned by using in-line sprayers or by directly putting it in disposal tanks. After that, the fruit is either washed with clean water or treated with fungicides. Many times to reduce the severity of post-harvest rot (except in the case of fungalresistant bacteria), fruits are firstly pre-filtered or stored, and then fungicides are often sometimes mixed with waxes. In potatoes, biopesticides and Bio-Save are used as a spray for 
the treatment before storage. The suitable construction of bio-controlling agents and Bio-save is a continuing concern. This product was first synthesized in liquid table powder or "frozen pellets" [17]. Brain-based disease control has been considered an alternative to chemistry. However, it still has to meet the expectations of effective disease control under the conditions of the field. However, many plant conservationists agree that biological control plays a vital role in controlling the number of germs in agricultural events. With only a handful of products available on the market, we remain unaware of any environmental limitations that may be biological control products. Although society has approved developing "green" strategies for "agricultural production", biological control has not received much effort in manufacturing chemical pesticides. With the decline in the tools to control products, there is a rapid acceleration of the development in plant disease control. In addition, there will also be a need to review the production methods used to treat plant diseases before the chemical era. Before discovering chemical fertilizers, natural supplements, like animal manure and compost, had made their way in agricultural fields for production because of their reproductive value. Due to reducing pathogens, these advancements also provide additional benefits like enhanced plant health [18]. The use of biodiversity supplementation in agriculture to grow crops and control soil pests peaked in the 1930s and was later widely described by Waksman $[19,20]$. In order to be effective in controlling organic diseases, their efficiency must be that of those used for pesticides. To achieve this, however, tools need to be developed to measure the effectiveness of environmental-based control products. We have been using a simple and measurable test that precisely calculates the effect of a product presented on a soil pathogen. Understanding how biological supplements (manure, compost) work also provides an understanding of how and where to suitably use such untapped energy resources for the betterment of plant and soil health. Natural nitrogen-fixing supplements (like poultry, meat and bone manure, and soy) have caused a subsequent reduction in the number of soil particles in plants carried by the soil. Pathogen control has been shown to be derived from ammonia and (or) nitrous acid produced. Its concentration is controlled by $\mathrm{pH}$, the content of natural matter, soil volume, and nitrification level. Pig manure can reduce the number of pathogens in both these processes and in the other process incorporating fatty acids. It has been reported that most of the fatty acids having $\mathrm{pH}$ below 6.0 are effective and are found in most but not all liquid fertilizers [21]. Disease control through biological control occurs when soil pathogen survival and biological material are reduced to activate the processes. Knowing the process and mechanisms permits the estimation of performance at the level of soil analysis and biodiversity amendments. In some products, for example, a product from the paper and powder industry, sulfonated lignin or ammonium lignosulfonate, the indication of disease control can the observed, but the mechanism is not yet clearly understood. Even though biological modification reduces the number of plant germs, it leads to a rise in soil microorganisms up to 1000 times per use. Therefore, pathogens' migration is discerning and may last in sectors for more than a few years after a sole application [21]. Many manufacturing and processing industries, plant pathologists, consumers, and farmers are using chemical products as a supplement to reduce soil diseases. Soil modification has been found to be an essential part of an integrated pest/pathogen management system and sustainable agricultural practice for farmers. Due to the reduced use of pesticides and consumers' demand and need for naturally enhanced products, this strategy is re-implemented. Additionally, the safe, economical, and right way to use or dispose of chemical products are the utmost important aspect for manufacturing, processing, and sanitation industries. Therefore, for this purpose, while some products are utilized by 
converting to animal fertilizer or feed, others are burned or mixed with soil. Despite discarding or disposing of, proper utilization is popular since it leads to growth in the market and provides market value to the re-used products. Also, it allows circulating nutrients and energy again into the world in its better form [21]. It was reported that high consumer interest for residual chemical products in food, implementation of domestic standards and guaranteed product exports, the strength of prices, and the common decrease in agricultural products in trade have in total pave the momentum to pest-free, organic, or natural farming [22].

\section{Comparison of Natural and Conventional Farming (in terms of crop protection)}

Natural or organic farming systems is a system that incorporates crops and livestock. This system often recycles and re-uses farm manure for composting and even applies biocontrol or methods to protect crops. Fertilizer, crop rotation, and soil farming techniques vary from conventional farming systems [23]. Generally, in conventional management practices, synthetic fertilizers and pesticides are often used and use organic fertilizers and avoided. Though biological changes have positively impacted various soil structures, the conventionalintegrated composting techniques make use of a blend of synthetic fertilizers [24]. In organic or natural farming, soil plays a major role in defining "sustainable land management" because it is the main root for food production. If the soil is worn or reduced to a larger degree, society can loosen its base for well-being and independence [25, 26]. Other common aspects of agriculture also have a negative impact on the environment and human health and higher prices. According to the "National Research Council Reports", the total cost of fertilizer application i.e., fertilizer in excess of the number of plants that can consume it is $\$ 2.5$ billion per year. In an estimate, the annual cost of soil erosion associated with public and environmental health exceeds $\$ 45$ billion [25]. The general sowing system of herbicides and its application represents standard feed for grain, crop line and uses a simple five-year cycle (maize, maize, beans, maize, beans) that reflects normal commercial activity in the region and across the Midwest. Fertilizer and pesticide applications for maize and soybeans follow the "Pennsylvania State University Cooperative Extension (PSUCE)" recommendations. To conserve the soil and water resources, crop residues are left on the earth's surface. Thus, this benefits the growing season, as no soil is exposed in the normal system than in legume systems [29]. The current framework is being analyzed, and the need to redefine the issue of the harvest gap is highlighted with regards to the questions like, "Can living feeds the earth?", "How can agriculture contribute to land tenure?". In addition, the challenges are based on the standards followed in existing yield comparison studies. They are completely based on different aspects of farming methods, after which a novel model is introduced to more clearly understand the type of harvesting spaces and estimates set in. Therefore, it can be concluded that "by establishing appropriate measures, prioritizing research needs, and focusing on natural resource transformation rather than input, biodiversity programs can increase their productivity and play a significant role in sustainable agriculture and food production in the future" [30]. Organic farming is becoming more and more popular around the world. The organic sowing system strictly bounds to the fact and principle that neither plant chemicals should be used nor mineral fertilizers. Additionally, such plants should be placed at the right place and at the correct interval with that of normal plants (consumer area). This aids in providing a better quality of agriculture with better properties [31,32]. In addition, as per the 'EU's Nitrate Directive', a viable agricultural system reduces the amount of nitrogen available in the soil [33]. Therefore, healthy and safe food production can be achieved by adopting such agricultural practices, even 
though the natural environment should be respected as nutritious, rich, and healthy soil is the "foundation" of food security. The cause of reduction in biodiversity and soil degradation is thought to be due to 'Agricultural consolidation' [34-36]. Organic matter, which is the basis of fertilization under the organic system or organic farming, provides the major positive impacts on soil quality, improved structure, increased water content, and soil infiltration. Several studies have revealed that organic farming methods aids in increasing soil activity by accumulating high organic matter and high chemical or micronutrients content. Therefore, one can achieve this by using host crops, animal manure, and other organic fertilizers, making use of crop residues, and decreasing agricultural activities such as farming. Conventional farming, too, often contributes to excessive soil accumulation of nitrogen, phosphorus, and potassium compounds not found in plants $[37,38]$. The type, type, and variety of plant species also have a significant impact on the chemical composition of the soil. Previous research suggests that root crops [31] and plants Fabaceae / Leguminosae [39,40] contribute to the formation of better soil chemicals and enzymatic properties than grain plants. This is due to the highly beneficial chemical composition of plant and powder residues entering the soil [41]. Conventional and organic agriculture have different values, even if lower inclusion practices are used in standard systems and standard organic comparisons are much smaller than continuous. The traditional approach thinks that the production of food, fiber, and fuel should be increased to meet the needs of growing people. Organic agriculture seeks to balance yields and other values, such as biodiversity and conservation of natural resources. The highest yields available for biodiversity should be kept at a lower level than normal if it will leave room for other species to survive and protect from environmental exploitation. The diversity of many species of insects and plants is negatively associated with fruit [42]. Recent research has also suggested using pesticides, increased fertilizer application, and intensive agriculture throughout the year as compelling reasons for the decline in biomass flight over 27 years [43]. Indigenous agriculture should not be judged by the production system driven by a standard agricultural product but rather by standards corresponding to its prices.

\section{Biological Pest Management, Its Techniques (Older (Import), Imported Inputs)}

\subsection{Ancient pest control or importation.}

"Classical Biological control is based on the introduction of natural enemies (parasites, predators, or pathogens) and their long-term formation in a new environment, a strategy that can provide long-term control of arthropod or targeted weeds". Such a biological control method is effective, as nearly hundreds of fruitful projects have minimized the harm caused by various weed-resistant pests [44, 45]. Between 1964 and 1976, around 170 successes were achieved by putting natural enemies in the second place after they were shown to be effective in the first place of introduction [46]. As many scientists worry about the extinction or loss of species and biodiversity, on the other hand, pest control experts focus on the addition of plant and animal fragments to agricultural systems. In 1971, the United States (U.S.) Department of Agriculture enforced a team to evaluate the performance of independent plants to prevent the access of rare pests and assess the risks associated with it [47]. They compiled a list of alien pests, and related arthropods in the U.S. classify immigrants as insects, beneficial species, and subspecies that are not economically important. The list keeps on increasing as more and more species become available. At the end of the 1971-1972 study, 1115 species were identified as foreign, and this number had risen to 1385 in 1977. Sixteen orders for insects, caterpillars 
(Acarina), and spiders (Araneae) are represented among different arthropod species. Old pest control has been used for nearly a century and has been very successful, which in economic terms has been surprisingly natural: the estimated return from dollar investment to pest control is about 301 , and chemical control (pesticides) is 5 to 51 [48]. However, biocontrol is not a panacea control insecticide, and the success achieved is more than just snow in the field. Of all biocontrol agents imported, only about $35 \%$ have been reported to be naturally established in the new ecosystem [49], and only about $60 \%$ of these facilities have any form of economic or biocontrol success [50]. De-Bach and Hagen [51] wrote: "One of the great obstacles to the work of biological control is that many natural enemies have been moved from one country to another in the same climate of failure". Perhaps the most commonly cited cause for failing adverse weather conditions at the time of departure $[52,53]$. Another important parameter of failure is occasionally mentioned in the world's review, the introduction [53]. The host-specific parasitoids are brought from the region of origin of an exotic invasive pest for implying biological control methods. Such a method aims to introduce the parasitoid established throughout the region selected by the invading insects and provide long-term suppression to low insect infestations. The invasion of 'Aphytis paramaculicornis' and 'Coccophagoides utilis' in California in the 1950s to control the olive scale (Pararlatoria oleae) provides a stellar example of the olive scale that is a rare insect in California about 50 years after the first parasitoid introduction [54, 55]. While there has been a series of significant success in combating pest infestations in many different regions of the world, there is still a huge list of failures where imported parasitoids have not been established in the target region or, if they do, have not had a significant impact on target pest infestation. Using the historical record of ancient biological introductions worldwide, only 3850 unique insect-introduced parasitoids have led to the establishment, and $44 \%$ of the 551 established parasitoids have provided part of total pest control, equivalent to an average of $17 \%$ overall of success [56, 57]. In contrast, insect repression is caused by an exotic parasitoid that begins to develop in a healthy environment. This process usually happens within six to 13 generations [58] and extends to a broader geographical scale $[59,60]$. Moreover, there is a rising indication that parasitoids may detect differences in the frequency of intercourse between distant patches using info-chemical signals [61, 62]. Therefore, selective decision-making by parasitoids determining the distribution of the parasitoid dietary effort between the patches may have a greater impact on the biological control factors of the past than dietary decisions made within patches.

\subsection{Inductive Inoculative Biological Pest Control.}

In addition to the introduction of natural enemies from the region of invasive insect habitats, biological controls include the occasional extraction of certain people from insect repression. Increased production of large parasitoids has led to the development of commercial pesticides in many parts of the world over the last 30 years, and it is predicted that more than 125 species of natural enemies are commonly accessible and utilized on around 16 million hectares worldwide per year [63]. At the beginning of the season, breeds of natural enemies in plants or in targeted surroundings, along with several inventors, are produced with the help of inoculative extracts. This continues throughout the growing season incorporating several stages of generation. One of the best inoculative supplementations of parasitoids is the use of "E. formula" to control greenhouse whitefly in Europe [64]. The aroma of the artificial plant plays a vital part in the food behavior of edible and animal arthropods. This was first demonstrated by predators, who, in search of spider larvae, made good use of plant volcanoes in response to 
spider attacks $[65,66,67]$. Insects that seek out caterpillars feed on healthy food as their reproductive organs use a similar strategy: they use volcanic-carrying volcanoes to find their food [68 - 73]. Wet extracts of insect parasitoids are applied rapidly to insects for getting instant effect on them, even without expecting successful breeding and passing on to future generations. In this way, the use of parasitoids in increasing energy can be compared with that of pesticides $[74,75]$. Therefore, water replenishment increases the ability to quickly kill parasitoids released rather than the parasitoid concentration potential in a series of generations. The entomopathogenic organic pest control biomarkers are similar to those of other pest control agents $[76,77]$. They can be used to add natural diseases (supplementation), stored or synthetic (conserved), used by insecticides as classical anti-control agents to establish and implement long-term pest control (inoculative release), or used for temporary control (release).

\section{Importance and Various Biological Controlling Agents}

Continuous invasion of biodiversity threatens biodiversity and the integrity of natural ecosystems [78]. Biological control is an essential means of combating biological attacks, but bio-control agents may cause a detrimental effect on indigenous species. Awareness of the risks accompanying change in the host has resulted in increased prominence on a specific host of invasive weed bio-control agents. Nevertheless, previous researches have suggested that biocontrol agents may also show significant non-target impacts by indirect communication or web-based support. Based on these observations, it can be concluded that the potential for interaction between biocontrol agents and their mediators is at least as important as the administrator's specification to determine the effect of biocontrol implants. Biocontrol agents are developed initially, but failure to reduce the effectiveness of their hostages can produce low-yielding links that link to other traditional weeds through food webs, thereby increasing the effects of invasive weeds. The indirect impact of certain bio-control regulating mechanisms resulting from dietary interventions could be a greater risk for native species than the direct effects of non-target at present seen in genetic modification [79].

Table 1. Importance and various biological controlling agents

\begin{tabular}{|c|c|c|c|}
\hline & Agents & Examples & References \\
\hline \multirow{4}{*}{ a) Insect pests } & - predators & $\begin{array}{l}\text { Spiders fall within the general area of } \\
\text { natural control factors. }\end{array}$ & [80] \\
\hline & - parasitism & $\begin{array}{l}\text { A. rhopalosiphi in the existence of } \\
\text { annual buck-wheat. }\end{array}$ & [81] \\
\hline & $\begin{array}{l}\text { - pathogens (Bacteria, Fungi, } \\
\text { Viruses, Oomycota) }\end{array}$ & $\begin{array}{l}\text { Verticillium lecanii and Hirsutella } \\
\text { thompsonii of fungi, Oryctes rhinoceros } \\
\text { (L.) of virus, Rhizobium of bacteria, } \\
\text { Phytophthora Infestans of oomycota, }\end{array}$ & {$[82,83,84,85]$} \\
\hline & - competitors & aphid honeydew on the leaf surface & {$[84]$} \\
\hline \multirow[t]{2}{*}{ b) Weeds } & - Seed predators & Chenopodium album L. & [86] \\
\hline & - herbivores & Cotesia flavipes & [87] \\
\hline c) Plant diseases & - Antagonist & $\begin{array}{l}\text { Heterobasidion annosum, } \\
\text { Agrobacterium radiobacter K84. }\end{array}$ & [89] \\
\hline
\end{tabular}

\section{Conservation and Enhancement of Biological Control Agent (Natural Enemies) of Pests}

Biodiversity management highlights the conservation as well as improvement of natural enemies and forms the foundation of all biological control methods. The efforts of recent and current research on the preservation of biodiversity control by predators and Bemisia parasites worldwide are taken into consideration. In many agricultural systems, a huge variety of natural 
enemy species have been identified. Additionally, other research has shown that these natural enemies can work with other death agents to create higher mortality rates for B people. Tabaci. Little effort has been put into determining what constitutes stressful or powerful factors in increasing biological control. The extensive use of pesticides in a variety of plants has strictly limited the effect of parasitoids and predators in reducing pests. Moreover, the stockpile of selected pesticides has full-fledged over the decades, and its ongoing use could permit for 'true integration' of biological control into 'IPM systems'. In addition, the factors of inter-breeding and plant characteristics treated in biological control disturbances are not well addressed in many systems [90]. Biodiversity management involves managing the environment to improve natural enemies' survival, abundance, permanency, and behavior to upsurge their effectiveness. Such management can lead to reducing risk factors and improving well-being. Conservation practices can be divided into categories; 1) those that focus on reducing mortality, 2) controlling secondary enemies, 3 ) modifying current plant characteristics for providing benefit to natural enemies, and 4) providing more resources [91, 92]. Biological control should be a significant element in all biological control efforts due to its quality of enhancing the performance and functioning of the natural enemy [93]. Such success has contributed to the very high cost of biodiversity management systems and has made the management of archaeology a very lucrative investment and development [94]. However, a recent analysis of the history of pest control history, the BIOCAT database, has shown that the percentage of entries contributing to success falls to a range of $5 \pm 15 \%$ [95]. Biodiversity management (CBC) aims to enhance the performance and function of natural enemies and help create safer ways to control biodiversity. Significant advancement has been made in this field over the years. The following articles, with a strong emphasis on arthropod CBC by arthropods, covered in this issue: 1) bee dew as a source of food for natural enemies, 2) the diversity of the natural enemy, 3) chemical environment and $\mathrm{CBC}$, 4) habitats, 5) non-food sprays, 6) the CBC in the landscape scale, 7) the economic and acceptance of the $\mathrm{CBC}$, and 8) the $\mathrm{CBC}$ as a provider of several environmental services. Research has shown that this interpretation in reducing pest damage, increased yields or quality, and better economic profits for farmers is still unusual. Thus, it can be said that future researchers should investigate the impact of CBC on these levels, and also it is crucial to understand better the factors and conditions that will lower the pests in the field. The expansion of ecosystem services without biological control is possible because of the greater potential of CBC. Additionally, attention paid to the economic benefits of this will tend to increase the chances of $\mathrm{CBC}$ acquisition as well [96]. The conservation and prevention of natural enemies perhaps is the oldest form of pest control. A similar method to control pests was enforced around 900 AD by Chinese citrus growers. They placed nests of the dangerous ant Oecophylla smaragdina F. on mandarin orange trees in order to reduce the number of leaf-feeding pests $[97,98,99]$. Biodiversity management can be broadly divided into three distinct areas: the study and strength of extinct natural enemies, the identification and use of resources that interfere with or enhance the natural enemy's function and function, and evaluate the effectiveness of [100] biological control. A published environmental control study denotes 'about $1 / 3^{\text {rd }}$ of all biological management documents in B. tabaci, and this series did not change over time'. Further analysis of this biological-control literature proposes that the detection of useful natural enemies includes quite large efforts in research. While several studies addressed the factors that either inhibit or enhance biological control [108] and the effects of insecticides on predators and parasitoids, very limited studies have emphasised the effectiveness of biological control [110-114], and many studies deliver initial or incomplete 
results - these three factors and their mechanisms consistent with their approaches [91, 101109].

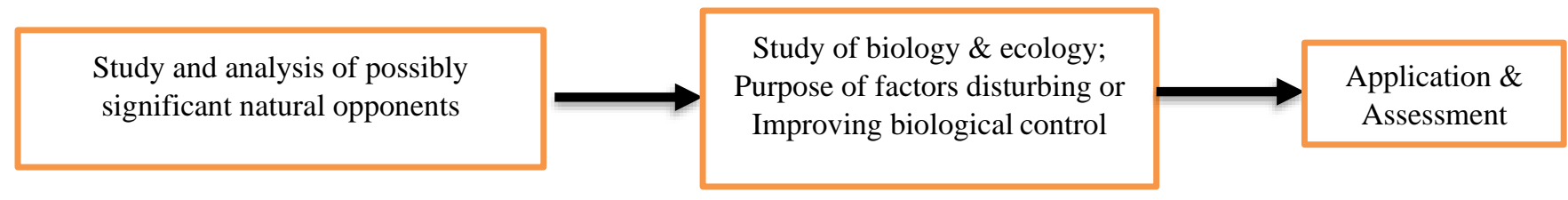

Figure 1. Components and approaches of conservation biological control [102,106,107].

\section{Discussion}

It has been observed that it is not easy to test the interaction of biological disease control agents with all creatures in surroundings and unidentified pathogenic relations with nontargeted fungi, florae, faunae, or bacteria that could be exposed after the issue. In the expression of cumulative intimidations to worldwide food safety and compression on normal possessions, there is crucial to classify and marketplace naturally founded crops as agricultural crop protect and yield accompaniments. The difficulties and tasks characteristic in the credentials, presentation valuation, and registration of biological disease control agents need important collaboration from administrative activities and the educational and manufacturing subdivisions to provide maintainable agriculture growth.

\section{Conclusions}

The release of biological disease control agents can be optimistic in relation to the manufacture of nutrition and fiber meanwhile, they are measured fewer poisonous to people and surroundings than artificial biochemical insecticides. However, the epidemic extent of numerous plant syndromes can be limited due to superior crop variety in period and interplanetary and the usage of normal plants, barriers, and asylum yields. Thus, a biological disease control agent would be observed as a conceivable risk until the technical proof has established that it is harmless. This will permit the use of bacterial causes through preserving passable nursing and investigation to agree on early discovery and extenuation of harmful organic and ecological influences.

\section{Funding}

This review received no external funding.

\section{Acknowledgments}

This review has no acknowledgment.

\section{Conflicts of Interest}

The authors declare no conflict of interest.

\section{References}

1. Haverkort, AJ.; Boonekamp, PM.; Hutten, R.; Jacobsen, E.; Lotz, LA.; Kessel, GJ.; Vossen, JH.; Visser, RG. Durable late blight resistance in potato through dynamic varieties obtained by cisgenesis: scientific and societal advances in the DuRPh project. Potato Research 2016, 59, 35-66, https://doi.org/10.1007/s11540015-9312-6. 
2. Ghyselinck, J.; Velivelli, SL.; Heylen, K.; O’Herlihy, E.; Franco, J.; Rojas, M.; De Vos, P.; Prestwich, BD. Bioprospecting in potato fields in the Central Andean Highlands: screening of rhizobacteria for plant growthpromoting properties. Systematic and applied microbiology 2013, 36, 116-27, https://doi.org/10.1016/j.syapm.2012.11.007.

3. Eilenberg, J.; Hajek, A.; Lomer, C. Suggestions for unifying the terminology in biological control. BioControl 2001, 46, 387-400, https://doi.org/10.1023/A:1014193329979.

4. Cook, RJ.; Thomashow, LS.; Weller, DM.; Fujimoto, D.; Mazzola, M.; Bangera, G.; Kim, DS. Molecular mechanisms of defense by rhizobacteria against root disease. Proceedings of the National Academy of Sciences 1995, 92, 4197-201, https://doi.org/10.1073/pnas.92.10.4197.

5. Jousset, A.; Lara, E.; Wall, LG.; Valverde, C. Secondary metabolites help biocontrol strain Pseudomonas fluorescens CHA0 to escape protozoan grazing. Applied and Environmental Microbiology 2006, 72, 708390, https://doi.org/10.1128/AEM.00557-06.

6. Mazzola, M.; de Bruijn, I.; Cohen, M. F.; Raaijmakers, J. M. Protozoan-induced regulation of cyclic lipopeptide biosynthesis is an effective predation defense mechanism for Pseudomonas fluorescens: Appl. Environ. Microbiol. 2009, 75, 6804-6811, https://doi.org/10.1128/AEM.01272-09.

7. Harman, GE. Myths and dogmas of biocontrol changes in perceptions derived from research on Trichoderma harzinum T-22. Plant disease 2000, 84, 37793, https://doi.org/10.1094/PDIS.2000.84.4.377.

8. Kendrick, B. The Fifth Kingdom, Mycologue Publications. Ontario, Canada, 1992.

9. Brimner, TA.; Boland, GJ. A review of the non-target effects of fungi used to biologically control plant diseases. Agriculture, Ecosystems \& Environment 2003, 100, 3-16, https://doi.org/10.1016/S01678809(03)00200-7.

10. Cook, RJ. Making greater use of introduced microorganisms for biological control of plant pathogens. Annual review of phytopathology 1993, 31, 53-80, https://doi.org/10.1146/annurev.py.31.090193.000413.

11. Harman, GE.; Taylor, AG.; Stasz, TE. Combining effective strains of Trichoderma harzianum and solid matrix priming to improve biological seed treatments. Plant Disease 1989, 73, 631-7.

12. Cook, RJ.; Baker, KF. The nature and practice of biological control of plant pathogens. American Phytopathological Society 1983.

13. Van Bruggen, AH.; Finckh, MR. Plant diseases and management approaches in organic farming systems. Annual review of phytopathology 2016, 54, 25-54.

14. Willer H, Lernoud J.; The world of organic agriculture. Statistics and emerging trends 2019. Research Institute of Organic Agriculture FiBL and IFOAM Organics International 2019.

15. Birkhofer, K.; Bezemer, TM.; Bloem, J.; Bonkowski, M.; Christensen, S.; Dubois, D.; Ekelund, F.; Fließbach, A.; Gunst, L.; Hedlund, K.; Mäder, P.; Mikola, J.; Robin, C.; Setala, H.; Tatin-Froux, F.; Van der Putten, W.H.; Scheu, S. Long-term organic farming fosters below and aboveground biota: Implications for soil quality, biological control and productivity. Soil Biology and Biochemistry 2008, 40, 2297-308, https://doi.org/10.1016/j.soilbio.2008.05.007.

16. Janisiewicz, WJ.; Korsten, L. Biological control of post-harvest diseases of fruits. Annual review of phytopathology 2002, 40, 411-41, https://doi.org/10.1146/annurev.phyto.40.120401.130158.

17. Lazarovits, G.; Tenuta, M.; Conn, KL. Utilization of high nitrogen and swine manure amendments for control of soil-borne diseases: efficacy and mode of action. International Symposium on Chemical and Non-Chemical Soil and Substrate Disinfectation 2000, 11, 59-64, https://doi.org/10.17660/ActaHortic.2000.532.5.

18. Waksman, SA. Principles of soil microbiology, 12-13, Baltimore, Williams and Wilkins Co. Md. London. 1927.

19. Comroe Jr., JH. Pay, dirt.; the story of streptomycin: Part I. From Waksman to Waksman. American Review of Respiratory Disease. 1978, 117, 773-81.

20. Lazarovits, G. Management of soil-borne plant pathogens with organic soil amendments: a disease control strategy salvaged from the past. Canadian Journal of Plant Pathology 2001, 23, 1-7, https://doi.org/10.1080/07060660109506901.

21. Conacher, AJ.; Conacher, J. Organic farming in Australia. Department of Geography, University of Western Australia, 1982.

22. Fließbach, A.; Oberholzer, HR.; Gunst, L.; Mäder, P. Soil organic matter and biological soil quality indicators after 21 years of organic and conventional farming. Agriculture, Ecosystems \& Environment 2007, 118, 27384, https://doi.org/10.1016/j.agee.2006.05.022.

23. Rosen, CJ.; Allan, DL. Exploring the benefits of organic nutrient sources for crop production and soil quality. HortTechnology 2007, 17, 422-30, https://doi.org/10.21273/HORTTECH.17.4.422.

24. Pimentel, D.; Harvey, C.; Resosudarmo, P.; Sinclair, K.; Kurz, D.; McNair, M.; Crist, S.; Shpritz, L.; Fitton, L.; Saffouri, R.; Blair, R. Environmental and economic costs of soil erosion and conservation benefits. Science 1995, 267, 1117-23, https://doi.org/10.1126/science.267.5201.1117.

25. Pretty, JN.; Brett, C.; Gee, D.; Hine, RE.; Mason, CF.; Morison, JI.; Raven, H.; Rayment, MD.; van der, Bijl G. An assessment of the total external costs of UK agriculture. Agricultural systems 2000, 65, 113-36, https://doi.org/10.1016/S0308-521X(00)00031-7.

26. Frankenberger, J.; Turco, R. Hypoxia in the Gulf of Mexico: A reason to improve nitrogen management. Purdue Animal Issues Briefing, 2005. 
27. National Research Council. Frontiers in agricultural research: Food, health, environment, and communities. National Academies Press; 2003.

28. US Department of Agriculture. 2003. Agricultural Statistics. Washington (DC): USDA.

29. Wilbois, KP.; Schmidt, JE. Reframing the debate surrounding the yield gap between organic and conventional farming. Agronomy 2019, 9, 82, https://doi.org/10.3390/agronomy9020082.

30. Kwiatkowski, CA.; Harasim, E.; Feledyn-Szewczyk, B.; Antonkiewicz, J. Enzymatic activity of loess soil in organic and conventional farming systems. Agriculture 2020, 10, 135, https://doi.org/10.3390/agriculture10040135.

31. Kwiatkowski, CA.; Haliniarz, M.; Harasim, E. Weed infestation and health of organically grown Chamomile (Chamomilla recutita (L.) Rausch.) depending on selected foliar sprays and row spacing. Agriculture 2020, 10, 168, https://doi.org/10.3390/agriculture10050168.

32. Biernat, L.; Taube, F.; Vogeler, I.; Reinsch, T.; Kluß, C.; Loges, R.; Is organic agriculture in line with the EU-Nitrate directive? On-farm nitrate leaching from organic and conventional arable crop rotations. Agriculture, Ecosystems \& Environment 2020, 15, 298, 106964, https://doi.org/10.1016/j.agee.2020.106964.

33. Brickle, NW.; Harper, DG.; Aebischer, NJ.; Cockayne, SH. Effects of agricultural intensification on the breeding success of corn buntings Miliaria calandra. Journal of Applied Ecology 2000, 37, 742-55, https://doi.org/10.1046/j.1365-2664.2000.00542.x.

34. Mozumder, P.; Berrens, RP. Inorganic fertilizer use and biodiversity risk: An empirical investigation. Ecological Economics 2007, 15, 538-43, https://doi.org/10.1016/j.ecolecon.2006.07.016.

35. Medan, D.; Torretta, JP.; Hodara, K.; Elba, B.; Montaldo, NH. Effects of agriculture expansion and intensification on the vertebrate and invertebrate diversity in the Pampas of Argentina. Biodiversity and Conservation 2011, 20, 3077-100, https://doi.org/10.1007/s10531-011-0118-9.

36. Shannon, D.; Sen, AM.; Johnson, DB. A comparative study of the microbiology of soils managed under organic and conventional regimes. Soil Use and Management 2002, 18, 274-83, https://doi.org/10.1111/j.1475-2743.2002.tb00269.x.

37. Wang, Y.; Tu, C.; Cheng, L.; Li, C.; Gentry LF, Hoyt GD, Zhang X, Hu S. Long-term impact of farming practices on soil organic carbon and nitrogen pools and microbial biomass and activity. Soil and Tillage Research 2011, 1, 8-16, https://doi.org/10.1016/j.still.2011.08.002.

38. Woźniak A. Chemical properties and enzyme activity of soil as affected by tillage system and previous crop. Agriculture 2019, 9, 262, https://doi.org/10.3390/agriculture9120262.

39. Harasim, E.; Antonkiewicz, J.; Kwiatkowski, CA. The effects of catch crops and tillage systems on selected physical properties and enzymatic activity of loess soil in a spring wheat monoculture. Agronomy 2020, 10, 334, https://doi.org/10.3390/agronomy10030334.

40. Kwiatkowski, CA.; Harasim, E.; Staniak, M.; Effect of catch crops and tillage systems on some chemical properties of loess soil in a short-term monoculture of spring wheat. Journal of Elementology 2020, 25, https://doi.org/10.5601/jelem.2019.24.2.1837.

41. Gabriel, D.; Sait, SM.; Kunin, WE; Benton, TG. Food production vs. biodiversity: comparing organic and conventional agriculture. Journal of applied ecology 2013, 50, 355-64, https://doi.org/10.1111/13652664.12035.

42. Hallmann, CA.; Sorg, M.; Jongejans, E.; Siepel, H.; Hofland, N.; Schwan, H.; Stenmans, W.; Müller, A.; Sumser, H.; Hörren, T.; Goulson, D.; de Kroon, H. More than 75 percent decline over 27 years in total flying insect biomass in protected areas. PloS one. 2017, 18, e0185809, https://doi.org/10.1371/journal.pone.0185809.

43. Laing, JE.; Hamai, J. Biological control of insect pests and weeds by imported parasites, predators, and pathogens. Biological control of insect pests and weeds by imported parasites, predators, and pathogens. Academic Press. New York USA, 1976, 685-743.

44. Clausen, CP.; Bartlett, BR.; DeBach, P.; Goeden, RD.; Legner, EF.; McMurtry, JA.; Oatman, ER.; Bay, EC.; Rosen, D. Introduced parasites and predators of arthropod pests and weeds: a world review [Biological control, economic plants]. Agriculture Handbook-US Dept. of Agriculture (USA) 1978.

45. Luck, RF.; Shepard, BM.; Kenmore, PE. Experimental methods for evaluating arthropod natural enemies. Annual Review of Entomology 1988, 33, 367-89, https://doi.org/10.1146/annurev.en.33.010188.002055.

46. Sailer, RI. History of insect introductions. In Exotic plant pests and North American agriculture, Elsevier 1983.

47. Tukey, JW.; Alexander, M.; Bennett, HS.; Brady, NC.; Calhoun Jr, JC.; Geyer, JC.; Haagen-Smit, AJ.; Hackerman, N.; Hartgering, JB.; Pimentel, D.; Revelle, R. Restoring the quality of our environment. Report of the environmental pollution panel, President's Science Advisory Committee. The White House. 1965.

48. Hall, R.; Ehler, LE. Rate of establishment of natural enemies in classical biological control. Bulletin of the ESA 1979, 25, 280-3, https://doi.org/10.1093/besa/25.4.280.

49. Hall, RW; Ehler, LE; Bisabri-Ershadi, B. Rate of success in classical biological control of arthropods. Bulletin of the ESA 1980, 26, 111-4, https://doi.org/10.1093/besa/26.2.111.

50. DeBach, P.; Hagen, KS. Manipulation of entomophagous species. Biological Control of Insect Pests and Weeds 1964. 
51. Turnbull, AL.; Population dynamics of exotic insects. Bulletin of the ESA 1967, 15, 333-7, https://doi.org/10.1093/besa/13.4.333.

52. Britton, J. R. Introduced parasites in food webs: new species, shifting structures?. Trends in ecology \& evolution, 2013, 28(2), 93-99. https://doi.org/10.1016/j.tree.2012.08.020.

53. Huffaker, CB.; Kennett, CE.; Tassan, RL. Comparisons of parasitism and densities of Parlatoria oleae (19521982) in relation to ecological theory. The American Naturalist 1986, 128, 379-93, https://doi.org/10.1086/284569.

54. Rochat, J.; Gutierrez, AP. Weather-mediated regulation of olive scale by two parasitoids. Journal of Animal Ecology 2001, 1, 476-90.

55. Mills, NJ. Biological control: some emerging trends. In Individuals, populations and patterns in ecology. 1994.

56. Mills, NJ. Biological control: the need for realistic models and experimental approaches to parasitoid introductions. In Parasitoid population biology 2000, 27, 217-34.

57. Bellows, TS. Restoring population balance through natural enemy introductions. Biological Control 2001 , 21, 199-205, https://doi.org/10.1006/bcon.2001.0936.

58. Thies, C.; Steffan-Dewenter, I.; Tscharntke, T. Effects of landscape context on herbivory and parasitism at different spatial scales. Oikos 2003, 101, 18-25, https://doi.org/10.1034/j.1600-0706.2003.12567.x.

59. Cronin, JT. Host-parasitoid extinction and colonization in a fragmented prairie landscape. Oecologia 2004, 139, 503-14, https://doi.org/10.1007/s00442-004-1549-8.

60. Geervliet, JB.; Ariëns, S.; Dicke, M.; Vet, LE. Long-Distance Assessment of Patch Profitability through Volatile Infochemicals by the ParasitoidsCotesia glomerataandC. rubecula (Hymenoptera: Braconidae). Biological Control 1998, 11, 113-21, https://doi.org/10.1006/bcon.1997.0585.

61. Vet, LE. Parasitoid searching efficiency links behaviour to population processes. Applied Entomology and Zoology 2001, 36, 399-408, https://doi.org/10.1303/aez.2001.399.

62. Van, Lenteren.; JC. Success in biological control of arthropods by augmentation of natural enemies. In Biological control: measures of success 2000, 77-103, https://doi.org/10.1007/978-94-011-4014-0_3.

63. Hoddle, MS.; Van Driesche, RG.; Sanderson, JP.; Biology and use of the whitefly parasitoid Encarsia formosa. Annual review of entomology 1998, 43, 645-69, https://doi.org/10.1146/annurev.ento.43.1.645.

64. Dicke, M.; Sabelis, MW. How plants obtain predatory mites as bodyguards. Netherlands journal of zoology. 1987, 38, 148-65, https://doi.org/10.1163/156854288X00111.

65. Dicke, M.; Van, Beek.; TA Posthumus, MV.; Dom, NB.; Van Bokhoven, H.; De Groot, AE. Isolation and identification of volatile kairomone that affects acarine predatorprey interactions Involvement of host plant in its production. Journal of chemical ecology 1990, 16, 381-96, https://doi.org/10.1007/BF01021772.

66. Dicke, M.; Sabelis, MW.; Takabayashi, J.; Bruin, J.; Posthumus, MA. Plant strategies of manipulating predatorprey interactions through allelochemicals: prospects for application in pest control. Journal of chemical ecology 1990, 16, 3091-118, https://doi.org/10.1007/BF00979614.

67. Turlings, TC.; Tumlinson, JH.; Lewis, WJ. Exploitation of herbivore-induced plant odors by host-seeking parasitic wasps. Science. 1990, 250, 1251-3, https://doi.org/10.1126/science.250.4985.1251.

68. Turlings, TC.; Loughrin, JH.; Mccall, PJ.; Röse, US.; Lewis, WJ.; Tumlinson JH. How caterpillar-damaged plants protect themselves by attracting parasitic wasps. Proceedings of the National Academy of Sciences 1995, 92, 4169-74, https://doi.org/10.1073/pnas.92.10.4169.

69. Steinberg, S.; Dicke, M.; Vet, LE. Relative importance of infochemicals from first and second trophic level in long-range host location by the larval parasitoid Cotesia glomerata. Journal of chemical ecology 1993, 19, 47-59, https://doi.org/10.1007/BF00987470.

70. Agelopoulos, NG.; Keller, MA. Plant-natural enemy association in tritrophic system, Cotesia rubecula-Pieris rapae-Brassicaceae (Cruciferae). III: Collection and identification of plant and frass volatiles. Journal of chemical ecology 1994, 20, 1955-67, https://doi.org/10.1007/BF02066236.

71. Shefali.; Sankhla, MS.; Kumar, R.; Sonone, SS. Phytomicrobiome Studies for Combating the Abiotic Stress. Biointerface Research in Applied Chemistry 2020, 11, 10493-10509, https://doi.org/10.33263/BRIAC113.1049310509.

72. Mattiacci, L.; Dicke, M.; Posthumus, MA. Induction of parasitoid attracting synomone in brussels sprouts plants by feeding of Pieris brassicae larvae: role of mechanical damage and herbivore elicitor. Journal of chemical ecology 1994, 20, 2229-47, https://doi.org/10.1007/BF02033199.

73. Tumlinson, JH.; Turlings, TC.; Lewis, WJ. Semiochemical complexes that mediate insect parasitoid foraging. Agricultural Zoology Reviews 1992.

74. Vet, LE.; Dicke, M. Ecology of infochemical use by natural enemies in a tritrophic context. Annual review of entomology 1992, 37, 141-72, https://doi.org/10.1146/annurev.en.37.010192.001041.

75. Ode, PJ.; Hardy, IC. Parasitoid sex ratios and biological control. In Behavioural ecology of insect parasitoids: from theoretical approaches to field applications. 2008, 30, 253-91, https://doi.org/10.1002/9780470696200.ch12.

76. Harper, JD. Applied epizootiology: microbial control of insects. In Epizootiology of Insect Diseases. 1987, 473-96. 
77. Mack, RN.; Simberloff, D.; Mark Lonsdale, W.; Evans, H.; Clout, M.; Bazzaz, FA. Biotic invasions: causes, epidemiology, global consequences, and control. Ecological applications 2000, 10, 689-710, https://doi.org/10.1890/1051-0761(2000)010[0689:BICEGC]2.0.CO;2.

78. Pearson, DE.; Callaway, RM. Indirect effects of host-specific biological control agents. Trends in Ecology \& Evolution 2003, 18, 456-61, https://doi.org/10.1016/S0169-5347(03)00188-5.

79. Riechert, SE.; Lockley, T. Spiders as biological control agents. Annual review of entomology 1984, 29, 299320, https://doi.org/10.1146/annurev.en.29.010184.001503.

80. Tylianakis, JM.; Didham, RK.; Wratten, SD. Improved fitness of aphid parasitoids receiving resource subsidies. Ecology 2004, 85, 658-66, https://doi.org/10.1890/03-0222.

81. Hall, RA.; Papierok, B. Fungi as biological control agents of arthropods of agricultural and medical importance. Parasitology 1982, 84, 205-40.

82. Bedford, GO. Biology, ecology, and control of palm rhinoceros beetles. Annual Review of Entomology 1980, 25, 309-39, https://doi.org/10.1146/annurev.en.25.010180.001521.

83. Pal, KK.; Gardener, BM. Biological control of plant pathogens. The plant health instructor 2006, 2, 1117-42, https://doi.org/10.1094/PHI-A-2006-1117-02.

84. Thines, M. Oomycetes. Current Biology 2018, 28, R812-3, https://doi.org/10.1016/j.cub.2018.05.062.

85. Blubaugh, CK.; Hagler, JR.; Machtley, SA.; Kaplan, I.; Cover crops increase foraging activity of omnivorous predators in seed patches and facilitate weed biological control. Agriculture, Ecosystems \& Environment 2016, 231, 264-70, https://doi.org/10.1016/j.agee.2016.06.045.

86. Turlings, TC.; Bernasconi, M.; Bertossa, R.; Bigler, F.; Caloz, G.; Dorn, S. The induction of volatile emissions in maize by three herbivore species with different feeding habits: possible consequences for their natural enemies. Biological control 1998, 11, 122-9, https://doi.org/10.1006/bcon.1997.0591.

87. Boyetchko, SM.; Rosskopf, EN.; Caesar, AJ.; Charudattan, R. Biological weed control with pathogens: search for candidates to applications. Applied mycology and biotechnology 2002, 2, 239-274, https://doi.org/10.1016/S1874-5334(02)80013-2.

88. Kerr, A. Biological control of crown gall through production of agrocin 84. Plant disease 1980, 64, 25-30.

89. Naranjo, SE. Conservation and evaluation of natural enemies in IPM systems for Bemisia tabaci. Crop protection 2001, 20, 835-52, https://doi.org/10.1016/S0261-2194(01)00115-6.

90. Rabb, RL.; Stinner, RE.; van den Bosch, R. Conservation and augmentation of natural enemies. Academic Press, New York; 1976.

91. Qureshi, SA.; Midmore, DJ.; Syeda, SS.; Reid, DJ. A comparison of alternative plant mixes for conservation bio-control by native beneficial arthropods in vegetable cropping systems in Queensland Australia. Bulletin of entomological research 2010, 100, 67-73, http://dx.doi.org/10.1017/S0007485309006774.

92. Gurr, GM.; Wratten, SD. FORUM 'Integrated biological control': A proposal for enhancing success in biological control. International Journal of pest management 1999, 45, 81, https://doi.org/10.1080/096708799227851.

93. Ehler, LE. Introduction strategies in biological control of insects. Critical issues in biological control/edited by Manfred Mackauer and Lester E. Ehler, Jens Roland. 1990.

94. Moraglio, ST.; Tortorici, F.; Giromini, D.; Pansa, MG.; Visentin, S; Tavella, L. Field collection of egg parasitoids of Pentatomidae and Scutelleridae in NW Italy and their evaluation on Halyomorpha halys in laboratory conditions. Entomologia Experimentalis et Applicata 2021, 169, https://doi.org/10.1111/eea.12966.

95. Jonsson, M.; Wratten, SD.; Landis, DA.; Gurr, GM. Recent advances in conservation biological control of arthropods by arthropods. Biological control $\mathbf{2 0 0 8 ,} \quad 45, \quad$ 172-5. https://doi.org/10.1016/j.biocontrol.2008.01.006.

96. Ehler, L. Conservation biological control: past, present, and future. In Conservation biological control 1998, 1-8, https://doi.org/10.1016/B978-012078147-8/50047-5.

97. Orr, D. Biological control and integrated pest management. In Integrated pest management: innovationdevelopment process 2009, 207-239, https://doi.org/10.1007/978-1-4020-8992-3_9.

98. Simmonds, FJ.; Franz, JM.; Sailer, RI. History of biological control. In Theory and Practice of Biological Control 1976.

99. Luck, RF.; Shepard, BM.; Kenmore, PE. Experimental methods for evaluating arthropod natural enemies. Annual Review of Entomology 1988, 33, 367-89, https://doi.org/10.1146/annurev.en.33.010188.002055.

100.Dwivedi, SA.; Tomer, A. Mass Production and Quality of Biological Control Agents for Pest Management. InRecent Developments in Microbial Technologies. Springer, 2021, 243-266, Singapore, https://doi.org/10.1007/978-981-15-4439-2_11.

101. Naranjo, SE. Conservation and evaluation of natural enemies in IPM systems for Bemisia tabaci. Crop protection 2001, 20, 835-52, https://doi.org/10.1016/S0261-2194(01)00115-6.

102.Martínez-Diz, M.D.P.; Díaz-Losada, E.; Andrés-Sodupe, M.; Bujanda, R.; Maldonado-González, M.M.; Ojeda, S.; Yacoub, A.; Rey,P.; Gramaje, D. Field evaluation of biocontrol agents against black-foot and Petri diseases of grapevine. Pest Manag. Sci. 2020, https://doi.org/10.1002/ps.6064. 
103.Berbegal, M.; Ramón-Albalat, A.; León, M.; Armengol, J. Evaluation of long-term protection from nursery to vineyard provided by Trichoderma atroviride SC1 against fungal grapevine trunk pathogens. Pest Manag. Sci. 2020, 76, 967-977, https://doi.org/10.1002/ps.5605.

104.Vukicevich, E.; Thomas Lowery, D.; Bennett, J.A.; Hart, M. Influence of groundcover vegetation, soil physicochemical properties, and irrigation practices on soil fungi in semi-arid vineyards. Front. Ecol. Evol. 2019, 7, 1-10, https://doi.org/10.3389/fevo.2019.00118.

105.Mahato, D.K.; Devi, S.; Pandhi, S.; Sharma, B.; Maurya, K.K.; Mishra, S.; Dhawan, K.; Selvakumar, R.; Kamle, M.; Mishra, A.; Kumar, P. Occurrence, Impact on Agriculture, Human Health, and Management Strategies of Zearalenone in Food and Feed: A Review. Toxins 2021, 13, 92, https://doi.org/10.3390/toxins13020092.

106.Mehta, R.; Shetty, S.A.; Young, M.F.; Ryan, P.B.; Rangiah, K. Quantification of aflatoxin and ochratoxin contamination in animal milk using UHPLC-MS/SRM method: A small-scale study. J. Food Sci. Technol. 2021, 58, 1-12, https://doi.org/10.1007/s13197-021-04986-w.

107.Dively, G.P.; Leslie, A.W.; Hooks, C.R.R. Evaluating wildflowers for use in conservation grass buffers to augment natural enemies in neighboring cornfields. Ecol. Eng. 2020, 144, 105703, https://doi.org/10.1016/j.ecoleng.2019.105703.

108.Hunt, LG.; Dively, G.; Hooks, CR. Flowering Chamaecrista fasciculata borders enhance natural enemy populations and improve grain quality in field corn. Agriculture, Ecosystems \& Environment 2021, 306, 107193, https://doi.org/10.1016/j.agee.2020.107193.

109.Cai, Z.; Ouyang, F.; Chen, J.; Yang, Q.; Desneux, N.; Xiao, Y.; Zhang, J.; Ge, F. Biological control of Aphis spiraecola in apples using an insectary plant that attracts and sustains predators. Biological Control 2021, 155, 104532, https://doi.org/10.1016/j.biocontrol.2021.104532.

110.Ricciardi, R.; Zeni, V.; Michelotti, D.; Giovanni, F.D.; Cosci, F.; Canale, A.; Zang, L.-S.; Lucchi, A.; Benelli, G. Old parasitoids for new mealybugs: Host location behavior and parasitization efficacy of Anagyrus vladimiri on Pseudococcus comstocki. Insects 2021, 12, 257 https://doi.org/10.3390/insects12030257.

111.Cocco, A.; Pacheco da Silva, V.C.; Benelli, G.; Botton, M.; Lucchi, A.; Lentini, A. Sustainable management of the vine mealybug in organic vineyards. J. Pest Sci. 2021, 94, 153-185 https://doi.org/10.1007/s 10340020-01305-8.

112.Pérez-Rodríguez, J.; Pekas, A.; Tena, A.; Wäckers, F.L. Sugar provisioning for ants enhances biological control of mealybugs in citrus. Biolog. Control 2021, 157, https://doi.org/10.1016/j.biocontrol.2021.104573.

113.Rondoni G.; Borges I.; Collatz J.; Conti E.; Costamagna A. Exotic ladybirds for biological control of herbivorous insects - a review. Entomologia Experimentalis et Applicata 2021, 169, https://doi.org/10.1111/eea.12963.

114.Schmidt, JM.; Acebes-Doria, A.; Blaauw, B.; Kheirodin, A.; Pandey, S.; Lennon, K.; Kaldor, AD.; Toledo, PF.; Grabarczyk, EE. Identifying Molecular-Based Trophic Interactions as a Resource for Advanced Integrated Pest Management. Insects 2021, 12, 358, https://doi.org/10.3390/insects12040358. 